\title{
UN EJEMPLO DE "CAPILLA ABIERTA" EN LA UNIVERSIDAD DE MAREANTES DE TRIANA
}

\author{
por Jose Maria Medianero HernandeZ
}

\begin{abstract}
Análisis comparativo sobre la tipología, configuración general y datación de la conocida "Capilla Abierta" que existió en la Universidad de Mareantes de Sevilla, situada en el arrabal de Triana frente al río Guadalquivir, matizando su carácter de precedente de las "Capillas Abiertas" hispanoamericanas por razones cronológicas.
\end{abstract}

This is a comparative analysis of the typology, general design and dating of the well-known «Capilla Abierta», or Open-air Chapel, of the Seafarers' University in Seville, situated in the outlying district of Triana facing the river Guadalquivir, with particular consideration of its role as precursor to Hispano-american «Open Chapels» on chronological grounds.

Desde la hiperbólica afirmación de Mac Andrew acerca de la extrema originalidad del atrio mexicano destacando la presencia de las "Capillas Abiertas" ', estas interesantes construcciones han oscilado entre las estimaciones que apoyan su singularidad y las refutaciones de esta pretensión, que suelen agotarse abundando en los comprobados precedentes europeos. No obstante, sin entrar en esta estéril polémica, resulta indudable y admitido por todos que la génesis de las "Capillas Abiertas" debe mucho a la especial coyuntura de las primeras décadas de evangelización en América y al deseo de concertar la funcionalidad requerida con la parquedad de medios, tanto humanos como materiales, a la hora de la construcción en esta etapa inicial.

Las similitudes tipológicas surgidas en la búsqueda de una utilidad parecida, con el análisis y reconstrucción aproximada de un ejemplo contemporáneo a su origen ęn una ciudad tan vinculada a América como es Sevilla, se constituye en el objetivo de este breve trabajo. Advirtiendo que, por este carácter de contempo-

1. The open-air churches of sixteenth-century Mexico. Atrios, posas, open chapels and other studies Cambridge, 1965, págs. 368 y ss. 
raneidad, en este caso no puede hablarse estrictamente de precedente, sino de coincidencia formal e incluso, cabe dentro de lo posible por la naturaleza de la institución donde se localizaba, de reflujo tipológico de tierras americanas.

\section{LA "CAPILLA ABIERTA" DE LOS MAREANTES}

Es conocida por distintos testimonios decimonónicos la existencia de una capilla exterior en la llamada en su tiempo Universidad de Mareantes, en la orilla de Triana. Tanto Justino Matute como González de León ofrecen unas sucintas y parejas descripciones de esta estructura para ellos "extraña". En esencia un "balcón o tribuna con un altar" sobre su puerta principal, finalizando con una frase prácticamente idéntica que cifra su utilidad en ofrecer la facilidad de cumplir los días de precepto la asistencia a la misa de "los ocupados en los bageles y los forzados en las galeras, sin necesidad de saltar en tierra" 2 .

Con mayor precisión, esta tribuna hubo de hallarse en la fachada de la iglesia orientada hacia el río, aneja al edificio del Hospital. Un reciente artículo de Francisco Ollero ha confirmado la afirmación tradicional de que el templo dedicado a la patrona de los Mareantes, la Virgen del Buen Aire, tenía puerta a la antigua Calle Larga (actual Pureza) y otra a la calle "Vera del río" (actual Betis), pero mientras ésta última era la portada principal de los pies aquélla se configuraba como una salida accesoría desde dependencias adosadas a la cabecera ${ }^{3}$.

Ya en otro lugar intenté reconstruir someramente la fisonomía de esta iglesia y en general de la sede edilicia de la Universidad de Mareantes ${ }^{4}$. En síntesis puede afirmarse que no debe hablarse de un edificio unitario, sino antes bien de un conjunto de construcciones. Por ejemplo, en una visita de los maestros competentes para unos arreglos en los edificios definen éstos como "la iglesia, capilla y caseríos en la calle que está sobre el río" s.

De este "caserío" parece fuera de duda que la pieza más importante sería la iglesia o capilla de la Virgen del Buen Aire. Su entidad se nos desvela entre la relación de las dificultades aducidas en el informe contrario a la construcción del

2. MATUTE y GAVIRIA, J. Aparato para escribir la Historia de Triana y su iglesia parroquial. Sevilla, 1818, págs. 127-8 y GONZALEZ DE LEON, F. Noticia histórica del origen de los nombres de las calles de esta M.N., M.L. y M. H. ciudad de Sevilla. Sevilla, 1839, pág. 564.

3. OLLERO LOBATO, F.: "El Hospital de Mareantes de Triana: Arquitectura y Patronazgo artístico" en el n.o 4 de la revista Atrio. Sevilla, 1992, pág. 61-70.

4. "La Capilla e imagen trianera de la Virgen del Buen Aire" en la revista Triana. N. ${ }^{\circ}$ de Otoño de 1989 (31), págs. 5-7.

5. BORREGO PLA, M." del C. Actas de la Universidad de Mareantes (Introducción de NAVARRO GARCIA, L.) Sevilla, 1972, pág. 247. 
Seminario o Colegio para niños de los marineros a partir de 1681 en Triana. Además de advertir la mala calidad de la construcción de las dependencias hospitalarias, se afirma que la iglesia ocupaba la mayor parte del inmueble ${ }^{6}$. No obstante, tanto las dimensiones como el valor artístico del templo debieron mantener un tono modesto; por algunas menciones, vertidas en cabildos referentes a reparaciones necesarias en tejados y las maderas que los sostenían, es de lógica suponer una cubrición por medio de artesonado de tradición mudéjar para un única nave rectangular, según el plano de 1778 hallado por Francisco Ollero.

Pero centrémonos en el dato que nos interesa aquí: la capilla exterior de la fachada que miraba hacia el río. Por los testimonios históricos se nos informa de un balcón o tribuna en alto sobre la puerta principal dominando la extensión frontera del curso fluvial. Una pintura fechada en 1650 permite aportar alguna precisión más acerca del particular. Se trata de una curiosa vista del Arenal de Sevilla en un cuadro al óleo anónimo conservado en la Hispanic Society de Nueva York ${ }^{7}$. Como es de rigor, al fondo se divisa una panorámica de las casas ribereñas al Guadalquivir de Triana y entre ellas, prácticamente al frente de la Torre del Oro como repiten los textos, se representa una que de forma casi certera debe tratarse de la fachada hacia el río de la iglesia de Ntra. Sra. del Buen Aire.

Efectivamente, se atisba un balcón sobre la puerta de entrada, muy simple en la pintura, o mejor sería decir balcón corrido de madera cubierto por tejadillo a un agua y protegido por una balaustrada asimismo muy sencilla y también lígnea. Dentro de este balcón se adivinan por las manchas de color vivo tres imágenes, que por su fisonomía y tonalidades podrían identificarse la central con la Virgen, de manto azulado, y sendos santos flanqueándola.

Sabemos, por cierto, que en la capilla externa de la iglesia que nos ocupa, detrás del altar, se situaba un tríptico o retablo de pequeño porte en el cual figuraba en el centro la Virgen titular del templo y dos Santos especialmente vinculados a la Hermandad de los Mareantes a cada lado. El siguiente aserto del Cabildo de la Universidad con fecha 23 de febrero de 1648 no ofrece duda alguna sobre lo dicho: "Y el retablo de Nuestra Señora, que está en el altar de la calle en el corredor sobre la puerta principal y tiene quebradas las puertas y las pinturas de los santos apóstoles San Pedro y San Pablo que iban en ella, y con el tiempo están gastados los colores, acordamos que todo se renueve y se hagan

6. HERRERA GARCIA, A. "Estudio histórico sobre el Real Colegio y Seminario de San Telmo" en Archivo Hispalense n. ${ }^{9} 88-90$. Sevilla, 1958, pág. 254.

7. Reproducido en el libro de CABRA LOREDO, M.” D. y SANTIAGO PAEZ, E. M. Iconografia de Sevilla. 1400-1650. Madrid, Ed. El Viso, 1988, pág. 205. 
puertas nuevas..." ${ }^{8}$. Todo apunta, por consiguiente, a que estas manchas de color de la pintura antedicha hagan referencia a este retablito o tríptico que se exhibía hacia el río.

\section{PARALELISMOS HISPANOAMERICANOS}

No es necesario encarecer las analogías de esta capilla externa trianera, tanto funcional como tipológicamente, con las "Capillas Abiertas" -también llamadas impropiamente "Capillas de Indios"- hispanoamericanas y, asimismo, no cabe entrar en su calidad de antecedente, aspecto que ya ha sido señalado y clasificado por el Prf. Jesús Miguel Palomero ${ }^{9}$.

Aquí interesa buscar las analogías específicas con el tipo de "Capilla Abierta" en alto, en la fachada de la iglesia, modalidad de la que E.W. Palm ha recabado incluso precedentes medievales ${ }^{10}$. En Nueva España tenemos ejemplos de esta tipología, con muestras estelares como las "Capillas Abiertas" de Acolman, Tlahuelipa o Huhaquechula, y tampoco faltan ejemplares de disposición idéntica esto es balconada sobre la puerta de ingreso-, como en la iglesia de Real del Monte, en el estado de Hidalgo, Tlacochahuaya y Tepecoacuilco ${ }^{11}$. También se encuentran en otros lugares, por ejemplo en la iglesia franciscana de Santiago de Atitlán, en Guatemala, con un balcón corrido sobre la portada principal ${ }^{12}$.

Sin embargo, donde este tipo de "Capilla Abierta" se muestra como especialmente abundante y característico es en el Virreinato del Perú. Superada queda la disquisición sobre la existencia de verdaderas "Capillas Abiertas" en la zona andina tras las apreciaciones de Marco Dorta, la investigación del matrimonio

8. BORREGO PLA, M. ${ }^{a}$ del C. o c., pág. 248. La presencia de San Pablo entra en contradición con las advocaciones expresadas en las Reglas de la Virgen del Buen Aire, San Pedro y San Andrés. Debe tratarse de un error del escribano. El Prof. J.M. Serrera ha puesto en relación las pinturas de este retablo con el pintor portugués activo en Sevilla Vasco Pereira. Vid. su artículo "Vasco Pereira, un pintor portugués en la Sevilla del último tercio del siglo XVI" en Archivo Hispalense, n.. 213. Sevilla, 1987, pág. 231.

9. "Antecedentes andaluces en las "Capillas de Indios" en Actas del I Congreso Internacional sobre los Dominicos y el Nuevo Mundo. Madrid, Deimos, 1988, págs. 927-8.

10. "Las Capillas Abiertas americanas y sus antecedentes en el Occidente cristiano" en Anales del Instituto de Arte Americano e Investigaciones Estéticas. Universidad de Buenos Aires. Facultad de Arquitectura y Urbanismo. N. 6, 1953, págs. 53-55.

11. El primer ejemplo se halla reproducido en el artículo de PALM, E. antes citado (Lám. 2) y los dos siguientes en el trabajo de GARCIA GRANADOS, R. "Capillas de indios en Nueva España (1530-1605)" en A.E.A.A. TOMO XI, 1935, págs. 3-29. Lám. VII y VIII respectivamente.

12. BONET CORREA, A. "Antecedentes españoles de las Capillas Abiertas Hispanoamericanas" en la Revista de Indias. Madrid, Enero-Junio de 1963, n.o 91-92, pág. 275. 
Mesa -Gisbert y, en especial, los documentados estudios del Prf. Bernales ${ }^{13}$. Lo cierto es que, al parecer, la forma más usual y quizás primigenia, sobre todo en la franja andina, fue un simple balcón de madera colocado directamente sobre la portada, en la fachada de los pies de la iglesia, al que se llegaba directamente desde el coro ${ }^{14}$.

Por testimonios documentales se sabe de la existencia de un balcón o "Capilla Abierta" ya en la primitiva Iglesia Mayor de Lima y se han detectado además varios restos en iglesias bolivianas ${ }^{15}$.

Generalmente en los pueblos de indios el balcón se abría sobre la plaza donde se reunía en masa a "los naturales" para recibir la doctrina. Es la fórmula que, por la frecuencia en ejemplos, llamó el Prf. Bernales "Capillas Abiertas de tipo cuzqueño".

Esta fórmula de balcón se complica en instalaciones como galerías de madera y, como caso de mayor complejidad arquitectónica, auténticas "loggias". Hasta tal punto que en el Perú puede decirse que predomina esta modalidad de "loggia", y así puede comprobarse en los ejemplos eximios del valle cuzqueño de San Jerónimo y Urcos ${ }^{16}$.

La balconada de la iglesia de Ntra. Sra. del Buen Aire, por la pintura antes mencionada, parece corresponder al aspecto de galería de madera, con sencillos pies derechos, barandal corrido y simple tejado a un agua o tejaroz de cubierta ${ }^{17}$. En este sentido recuerda testimonios como los de las iglesias de Sto. Domingo y la Merced de Ayacucho o, mejor, el balcón-galería de la fachada de Andahuaylillas en la zona cuzqueña.

Adviértase que en el caso de la "Capilla Abierta" trianera, para adecuarse perfectamente con la función requerida y vocación de la institución de los Mareantes, se cambió la orientación tradicional litúrgica del templo, colocando los pies de la iglesia hacia el Este. El cambio era forzoso en una iglesia volcada hacia la zona ribereña y con una capilla externa sobre la puerta para oficiar la misa a los marineros del río. Probablemente, el acceso hasta la balconada se realizaría desde el coro, a través de la misma escalera que subía hasta éste, como se ha comprobado en bastantes ejemplos andinos.

13. Recuérdese su ponencia al Congreso del C.E.H.A. celebrado en Granada en 1973 y su artículo "Capillas abiertas en las parroquias andinas del Perú en los siglos XVI y XVII" en Arte y Arqueología. Revista del Instituto de Estudios Bolivianos, n. 3 y 4. La Paz, 1975, págs. 113-129.

14. Vid. GISBERT, T. y MESA, J. de Arquitectura Andina. Historia y Análisis. La Paz, 1985, pág. 147 y BERNALES BALLESTEROS, J. o c., pág. 115.

15. GISBERT, T. y MESA, J. de o. c., págs. 146-7 y BERNALES BALLESTEROS, J. o. c., págs. 119-120.

16. GISBERT, T. y MESA, J. de o. c., págs. 147-8.

17. Vid. Reconstrucción ideal. Lám. 1. 
Parece claro que la función primordial de la "Capilla Abierta" de la Universidad de Mareantes era la de ofrecer la Eucaristía en los días de precepto a la marinería, tripulaciones, galeotes y personal ocupado en las labores propias de sus menesteres en el vasto panorama frontero del Guadalquivir. Sin embargo, el retablo con la figura central de la Virgen del Buen Aire asume también de alguna manera la ostentación al exterior de la imagen titular de la Cofradía conectando con la costumbre de la zona peruana de mostrar las imágenes, en lucha contra la idolatría, sobre todo en las llamadas "Capillas Absidales".

La presencia, no obstante, de este retablo parece incardinarse con más propiedad en la tónica de muchas "Capillas Abiertas" tanto españolas como americanas dedicadas fundamentalmente a la celebración de la Misa, que contuvieron imágenes, retablos y ante todo pintura mural. En verdad la misión de la "Capilla Abierta" de los Mareantes se descubre idéntica, en cuanto al ofrecimiento del culto a una masa de personas al aire libre, a la que desempeñaron la gran mayoría de las "Capillas Abiertas" hispanoamericanas. O mejor sería decir, recordando palabras de Toussaint cuando habla acerca de la "Capilla Abierta", fuera del contexto del atrio coventual: "la capilla abierta en vez de ayudar a los fieles para que asistan a las ceremonias, va en busca de ellos para que sin ninguna molestia puedan presenciar el culto" 18 .

En realidad, esta intención se relaciona con la función misma del sacerdocio y el espíritu de las órdenes mendicantes de raíces medievales, uno de cuyos fundamentos era que los fieles nunca quedasen sin oír misa fuera por la razón que fuese. Conocido son los casos de las "Capillas Abiertas" en mercados y el Marqués de Lozoya nos recuerda que en la Provincia de Segovia, hasta hace algunos años, en la época del esquileo de ovejas, se decía misa en los grandes barracones donde tenía lugar el trabajo, para que los esquiladores no renunciasen a oír misa por la premura necesaria de estas labores ${ }^{19}$.

La institución de los Mareantes hispalenses, asimismo, construyó una "Capilla Abierta" en su iglesia para que "su gente", los trabajadores de los barcos y la marinería activa en el río, pudiesen cumplir sus obligaciones religiosas si moverse de su lugar de trabajo y cesando sólo un corto espacio de tiempo entre las intensas y necesariamente rápidas labores de carenado, arreglo o pintura de los buques.

18. Arte Colonial en México. Ed. de la Universidad Nacional Autónoma de México, 1983, pág. 14.

19. Citado por BONET CORREA, A. en o. c., págs. 274-5. 


\section{DATACION DE LA "CAPILLA ABIERTA" TRIANERA}

Probados los paralelos tanto formales como funcionales de esta construcción sevillana con las "Capillas Abiertas" hispanoamericanas, sólo resta para terminar con las intenciones de este modesto trabajo determinar la cronología de este testimonio desaparecido, ya que de su datación pueden desprenderse consideraciones obviamente provechosas.

La institución que nos interesa surge documentalmente a la luz en 1555 , otorgando un poder a favor del cofrade y cosmógrafo del Rey Don Sancho Gutiérrez y autotitulándose "Cofradía y Hermandad de los Pilotos y Maestros que andan el camino de Indias, que hacemos nuestro Ayuntamiento en la Casa del Espíritu Santo, de Triana" ${ }^{20}$. Así pues, por estos años mediales del siglo XVI, esta asociación se reunía en "la Casa del Espíritu Santo, de Triana", es decir en el desaparecido convento agustino del "Sancti Spiritus", situado aproximadamente a la altura de la actual calle Luis de Cuadra. La primitiva agrupación de Mareantes comenzaría a reunirse en una dependencia cedida de dicho convento y más tarde, muy cerca, siguiendo la "Calle Larga de Sta. Ana" (actual Pureza), construir un edificio propio.

En efecto, en 1562 los "maestres, pilotos, capitanes y señores de naos", dándose el nombre de Universidad -es decir agrupación que reúne a los individuos de una misma actividad profesional - celebra sus reuniones ya en "el hospital que estamos haciendo en Triana" ${ }^{21}$. Por tanto, en este año su sede no está plenamente terminada. También por entonces se redactan sus primeras reglas: la de la Cofradía en 1561 y la de la Hermandad al año siguiente, aprobadas ambas conjuntamente por Felipe II en Galapagar el 22 de Marzo de $1569^{22}$.

Con certeza sabemos que en 1573 se finalizó lo más importante de la sede de la Universidad de Mareantes, ya que en este año se bendijo templo y hospital ${ }^{23}$. Pero este hecho no implica necesariamente que no estuviesen terminados estos edificios unos años antes. En este sentido, en el magnífico dibujo a pluma del flamenco Anton van den Wyngaerde ${ }^{24}$ trazado en 1567, se observa tras el voluminoso ábside de Sta. Ana un edificio con balcón alto sobre su puerta que muy

20. LOPEZ MARTINEZ, C. "La Hermandad de Sta. María de Buen Aire de la Universidad de Mareantes" en Anuario de Estudios Americanos I. Sevilla, 1944, pág: 707.

21. BORREGO PLA, M. ${ }^{a}$ del C. "Los hermanos de la Cofradía de Mareantes en el siglo XVI" en II Jornadas de Andalucía y América. Sevilla, 1984, págs. 362-3.

22. VEITIA LINAJE, J. Norte de la Contratación de Indias. Sevilla, 1672, pág. 113.

23. NAVARRO GARCIA, L. "Pilotos, Maestres y Señores de Naos en la Carrera de las Indias" en Archivo Hispalense, n. ${ }^{9}$ 141-146. Sevilla, 1967, pág. 294.

24. Se conserva en Viena, Österreichische Nationalbibliothek. Reproducido en CABRA LOREDO, M. D. y SANTIAGO PAEZ, E. M. ‥ o. c., pág. 72-74. 
probablemente se trate de la "Capilla Abierta" de la iglesia de los Mareantes. En el dibujo, el edificio aparece señalado con la letra $K$, que en la leyenda se identifica con el término "Spirito Sancta", que hace pensar en la localización del Convento del Espíritu Santo antedicho.

Ahora bien, algunos autores sostienen que la advocación original del Hospital de la Universidad de Mareantes fue la del Espíritu Santo o que fue emplazado cerca de la calle de este nombre ${ }^{25}$. Además, ya advertí en otro lugar la repetida confusión de autores del pasado en el respectivo emplazamiento de la Universidad de Mareantes y Convento del Espíritu Santo, dado que ambos eran contiguos, ocupando gran parte de este frente del río con sus respectivos caseríos anejos ${ }^{26}$.

El dibujo y lo que conocemos de esta "Capilla Abierta", tanto de tipología como en la localización del edificio en el conjunto urbano, coinciden punto por punto; todo lleva a pensar que el dibujante flamenco reflejó la advocación primitiva del Hospital o, quizás más probablemente, cayó en la confusión antes señalada, tanto más cuanto que cuando realizó su vista la Universidad de Mareantes como institución estaba aún en ciernes, dado que su regla no se aprobaría definitivamente hasta 1569 , como se ha dicho. Desde luego, el dato de la aparición de la balconada es significativo para situar la terminación de la fachada al río de la iglesia con su "Capilla Abierta" entre 1562 y 1567.

Con estas fechas nos situamos en unos parámetros cronológicos contemporáneos o poco posteriores a la realización de los principales ejemplos de las "Capillas Abiertas" de Nueva España e inmediatamente anteriores a las primeras construcciones de este tipo en el Virreinato del Perú ${ }^{27}$.

Como adelanté al principio no puede hablarse estrictamente de precedente, por este carácter de contemporaneidad inmediata ${ }^{28}$. Estimo que debe verse aquí una coincidencia formal en respuesta a una funcionalidad similar en estas construcciones, cuestión que podría esclarecerse con una investigación detallada acerca de los posibles ejemplos de "Capillas Abiertas" localizadas en puertos marítimos y fluviales del Virreinato del Perú. Todo ello en una coyuntura interpretada por elementos humanos de una mentalidad análoga desde el punto de vista espiritual, y sin descartar ya en tiempos tan tempranos las posibles sugerencias de lo

25. Vid. NAVARRO GARCIA, L. o. c., pág. 294 y LOPEZ MARTINEZ, C. o. c., pág. 709.

26. MEDIANERO HERNANDEZ, J. M. "La Capilla e imagen trianera de la Virgen del Buen Aire" o. c., págs. 3 y 5 .

27. Concretamente en la zona andina, donde los parangones sustentados son más claros, se empiezan a construir en su mayoría en tiempos del Virrey Toledo, hacia la década de los setenta del siglo XVI. Vid. BERNALES BALLESTEROS, J. o. c., pág. 116.

28. Cfr. PALOMERO PARAMO, J. M. o. c., pág. 919. 
que se estaba gestando en América; porque los hombres que levantaron esta iglesia eran, con palabras del título de sus reglas: "los señores de naos, maestros y capitanes y pilotos que navegan la Carrera de Indias para la Cofradía de Nuestra Señora del Buen Aire, San Pedro y San Andrés, que tienen establecida en Triana, a orillas del río" ${ }^{29}$.

29. Publicadas en Sevilla por Alonso Escribano en 1578. 


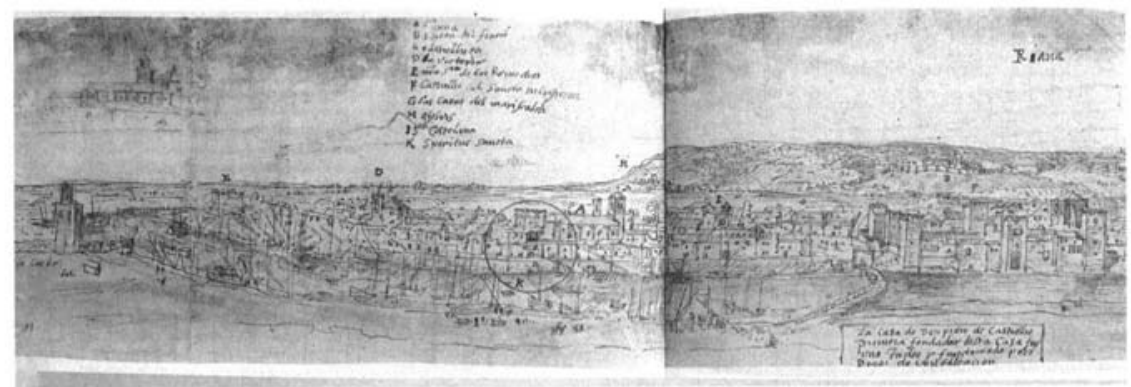

1. Vista de Triana. Anton van den Wyngaerde (1567), Viena, Österreichische Nationalbibliothek. 


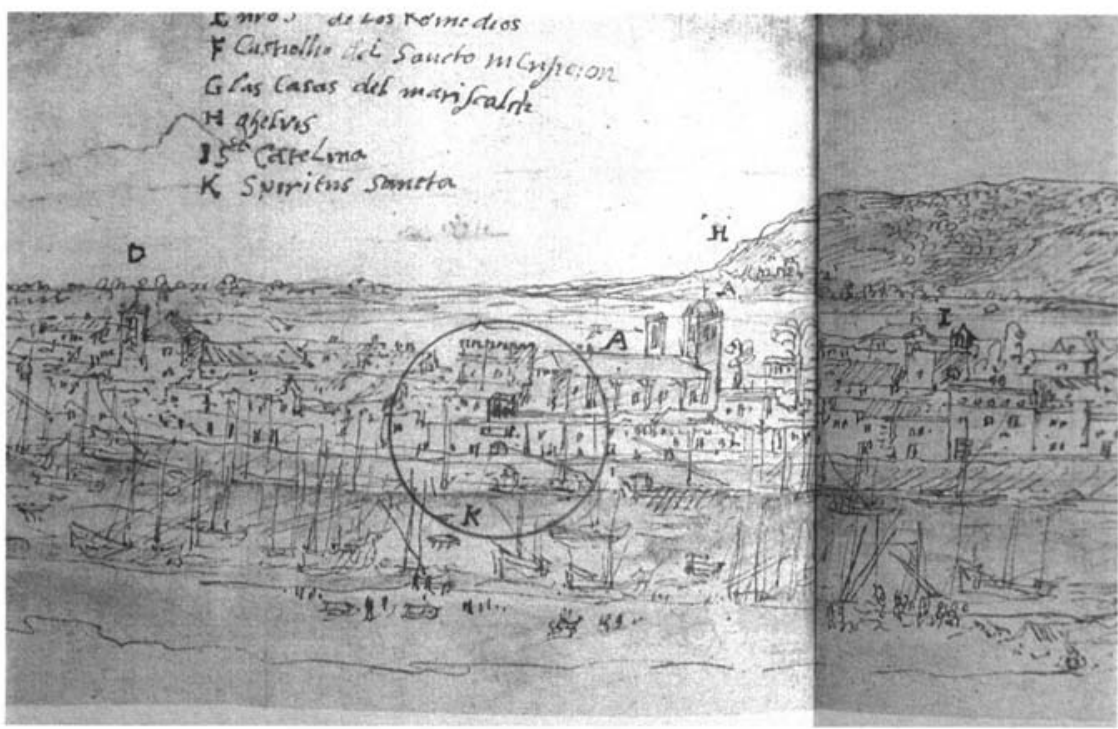

2. Detalle de la fachada de la iglesia de Ntra. Sra. del Buen Aire en la vista anterior. 


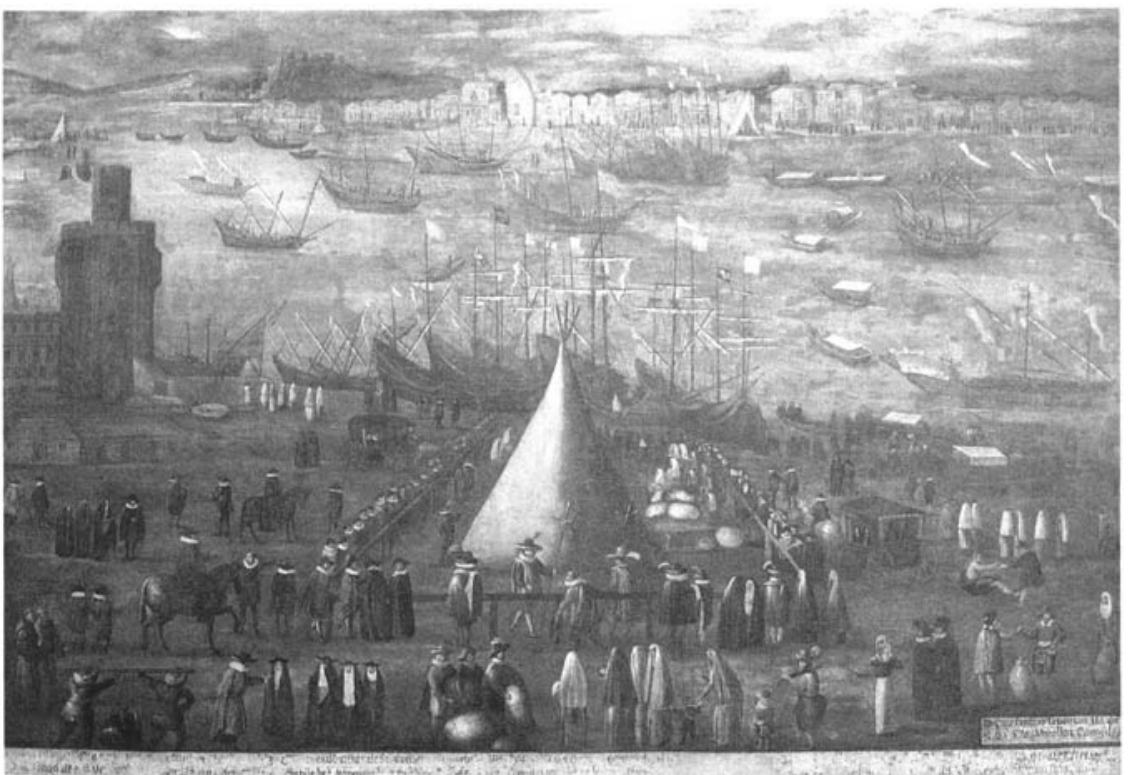




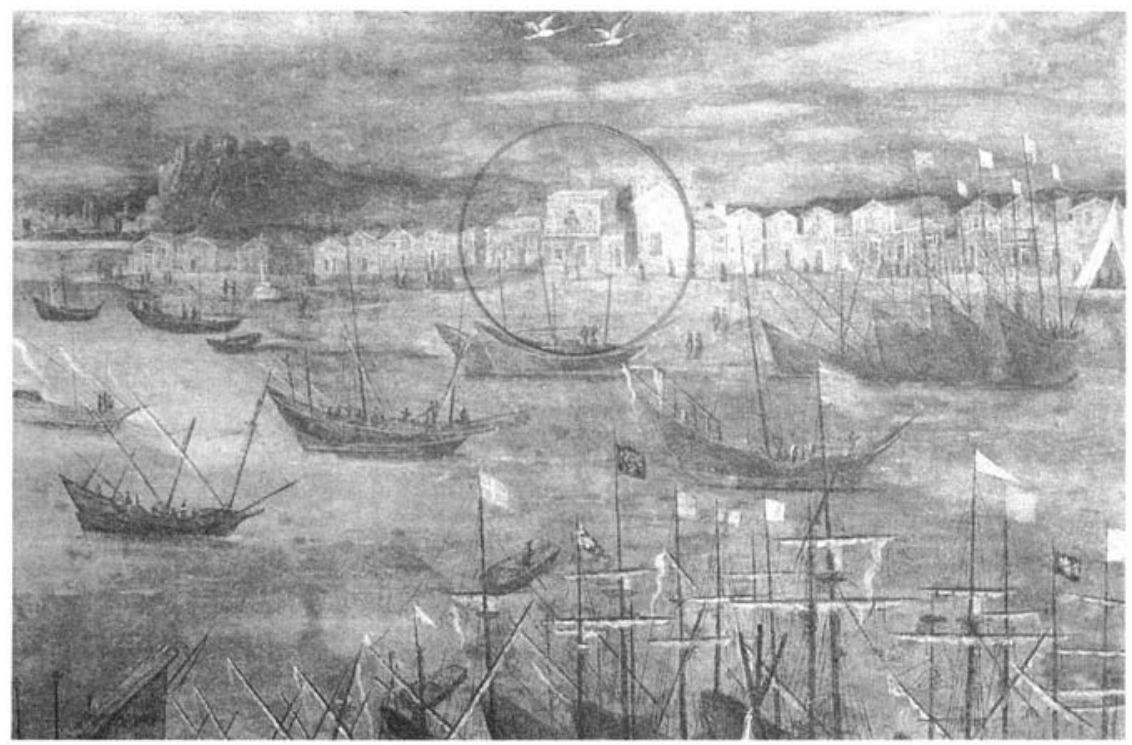

4. Detalle de la fachada de la iglesia de Ntra. Sra. del Buen Aire en la pintura anterior. 


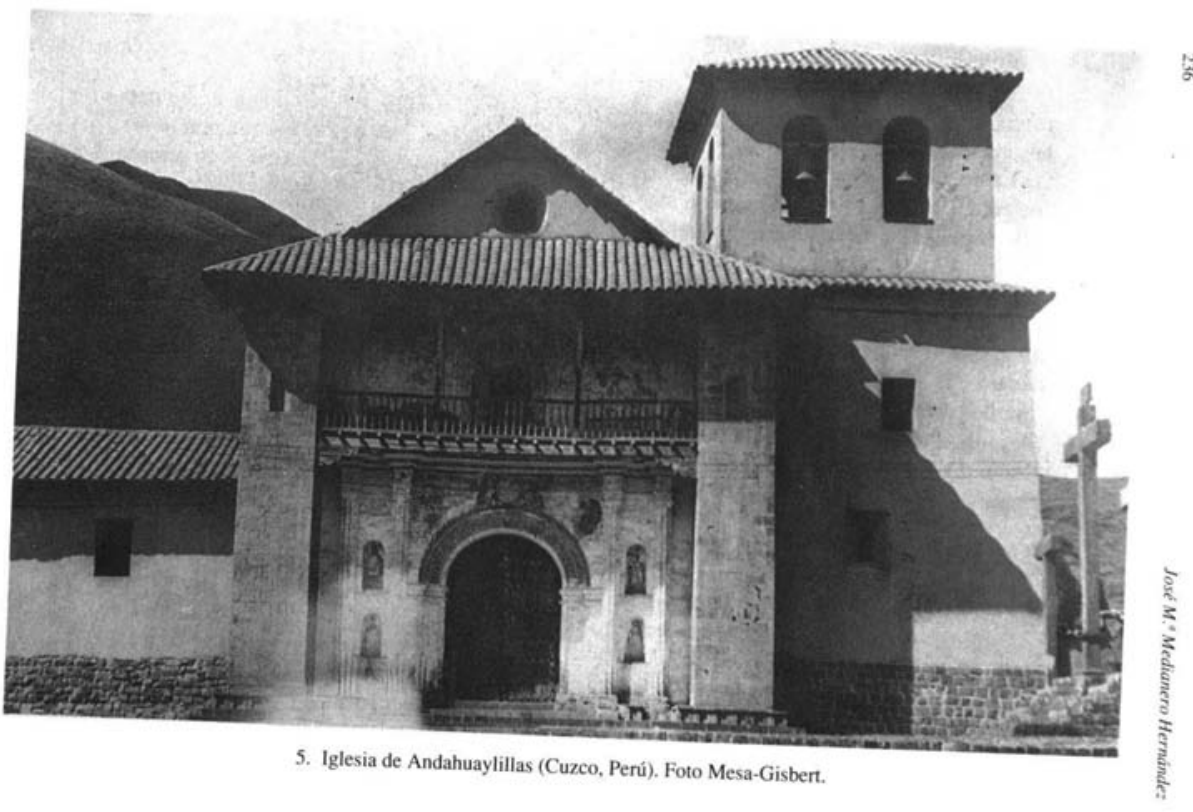




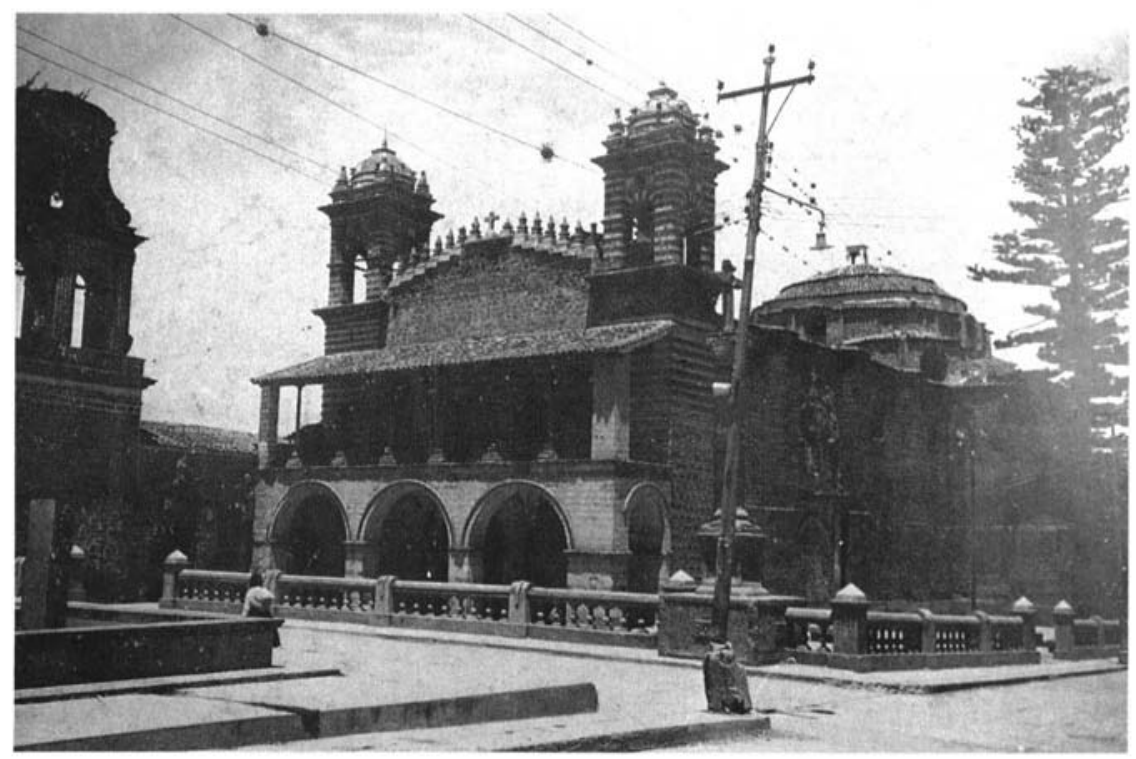

6. Iglesia de Sto. Domingo (Ayacucho, Perú). Foto Mesa-Gisbert. 


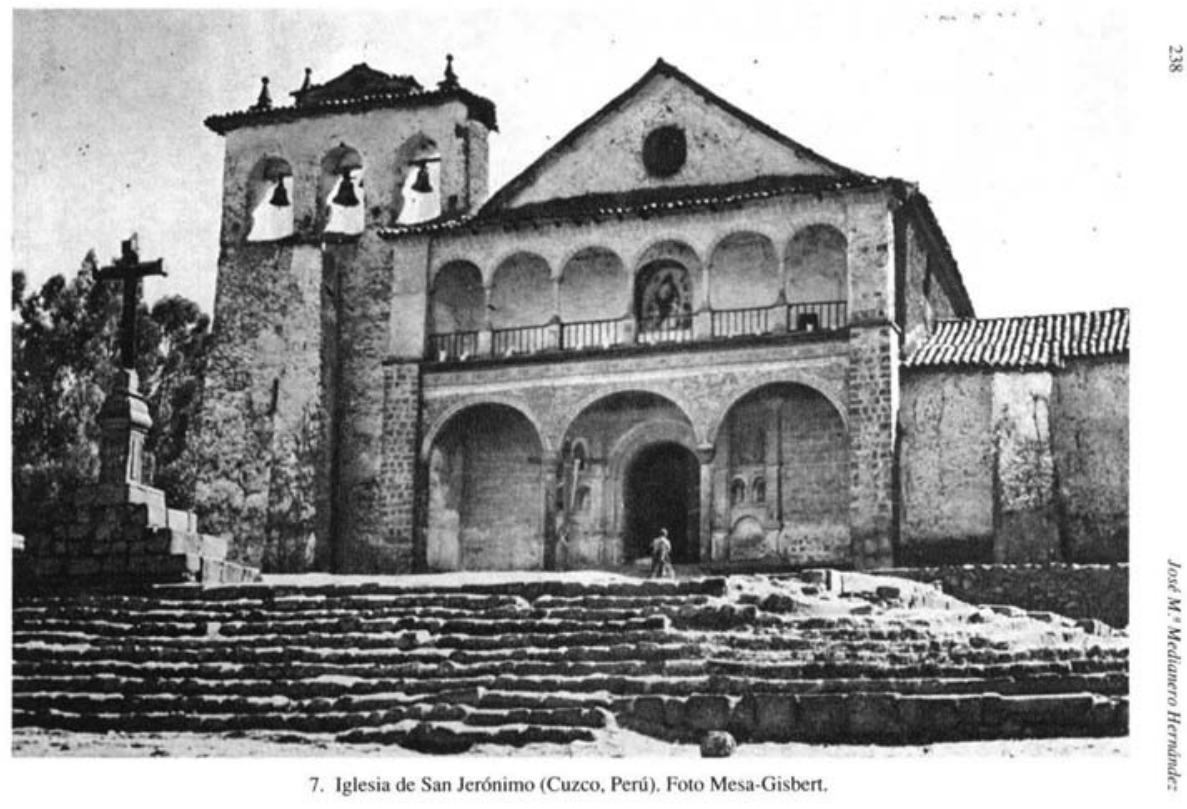




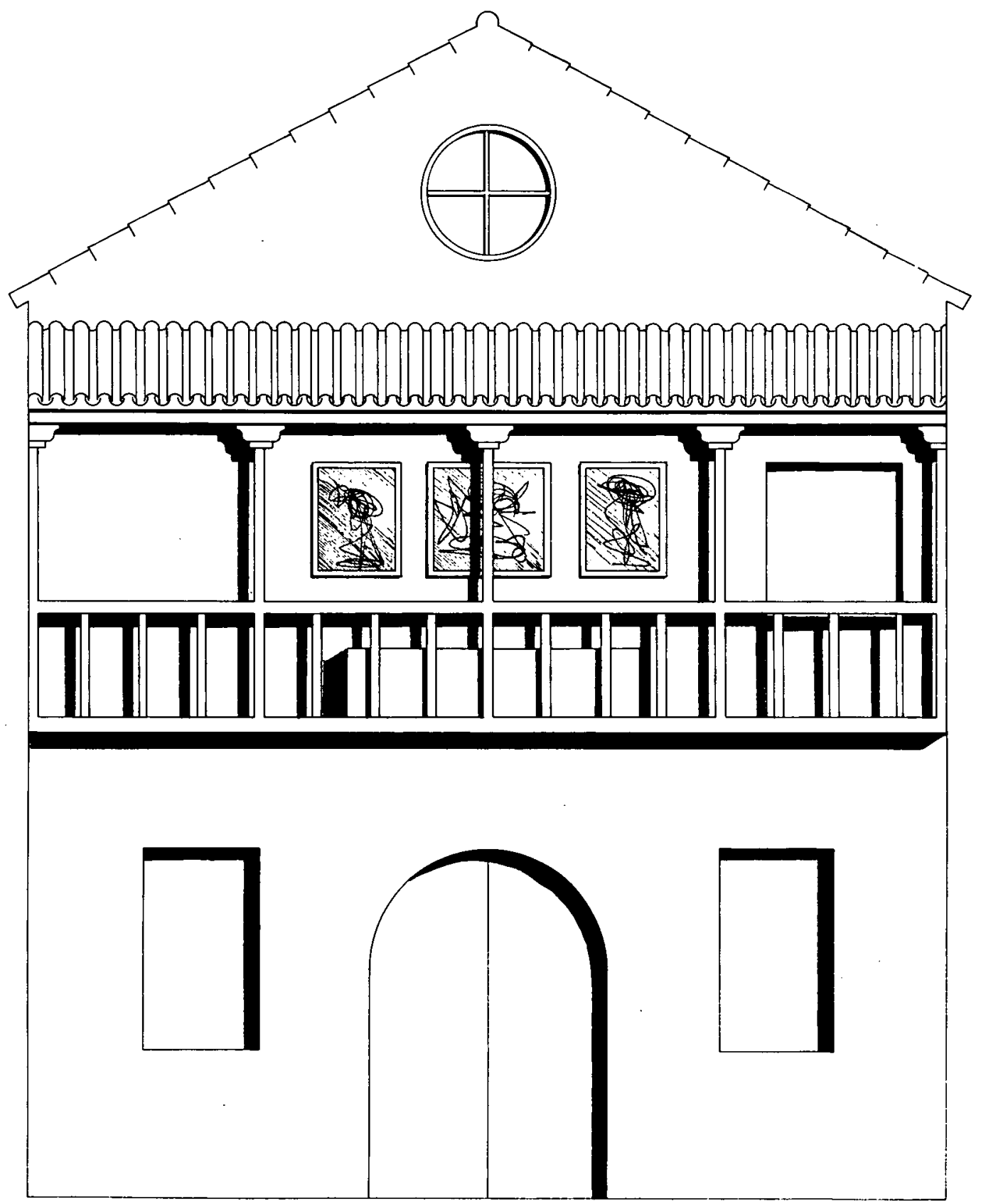

Lám. 1 Reconstrucción ideal de la fachada hacia el río de la iglesia de Ntra. Sra. del Buen Aire con su "Capilla Abierta". 